\title{
Prevalence, Molecular Characterization and Antimicrobial Susceptibility of Clostridioides difficile Isolated from Pig Carcasses and Pork Products in Central Italy
}

\author{
Caterina Licciardi ${ }^{1}$, Sara Primavilla ${ }^{1, *} \mathbb{0}$, Rossana Roila ${ }^{2, *} \mathbb{0}$, Alessia Lupattelli ${ }^{1}$, Silvana Farneti ${ }^{1}$, \\ Giuliana Blasi ${ }^{1}\left[{ }^{10}\right.$, Annalisa Petruzzelli ${ }^{1}$, Ilenia Drigo ${ }^{3}$ () and Enrico Di Raimo Marrocchi ${ }^{1}$ \\ 1 Istituto Zooprofilattico Sperimentale dell'Umbria e delle Marche "Togo Rosati", Via Salvemini 1, \\ 06126 Perugia, Italy; caterina.licciardi@gmail.com (C.L.); a.lupattelli@izsum.it (A.L.); s.farneti@izsum.it (S.F.); \\ g.blasi@izsum.it (G.B.); a.petruzzelli@izsum.it (A.P.); e.diraimo@izsum.it (E.D.R.M.) \\ 2 Department of Veterinary Medicine, University of Perugia, Via San Costanzo 4, 06126 Perugia, Italy \\ 3 Istituto Zooprofilattico Sperimentale delle Venezie, Vicolo Mazzini 4, 31020 Treviso, Italy; idrigo@izsvenezie.it \\ * Correspondence: s.primavilla@izsum.it (S.P.); rossana.roila@unipg.it (R.R.); Tel.: +39-075343213 (S.P.); \\ +39-0755857936 (R.R.)
}

Citation: Licciardi, C.; Primavilla, S.; Roila, R.; Lupattelli, A.; Farneti, S.; Blasi, G.; Petruzzelli, A.; Drigo, I.; Di Raimo Marrocchi, E. Prevalence, Molecular Characterization and Antimicrobial Susceptibility of Clostridioides difficile Isolated from Pig Carcasses and Pork Products in Central Italy. Int. J. Environ. Res. Public Health 2021, 18, 11368. https:// doi.org/10.3390/ijerph182111368

Academic Editors:

Teresa Semedo-Lemsaddek and David Rodríguez-Lázaro

Received: 25 September 2021

Accepted: 27 October 2021

Published: 29 October 2021

Publisher's Note: MDPI stays neutral with regard to jurisdictional claims in published maps and institutional affiliations.

Copyright: (c) 2021 by the authors. Licensee MDPI, Basel, Switzerland. This article is an open access article distributed under the terms and conditions of the Creative Commons Attribution (CC BY) license (https:// creativecommons.org/licenses/by/ $4.0 /)$.

\begin{abstract}
In the last decade, the incidence and severity of Clostridioides difficile infections (CDIs) in humans have been increasing and community-associated infections have been described. For these reasons, the interest in $C$. difficile in food and in food animals has increased, suggesting other possible sources of $C$. difficile acquisition. This study evaluated the presence of $C$. difficile on pig carcasses at the slaughterhouse and in pork products in Central Italy. The contamination rate on pig carcasses was $4 / 179$ (2.3\%). Regarding food samples, a total of 216 pork products were tested (74 raw meat preparations and 142 ready-to-eat food samples made by cured raw meat). The real-time PCR screening was positive for $1 / 74$ raw meat preparation $(1.35 \%)$ and for $1 / 142$ ready-to-eat food samples $(0.7 \%)$ C. difficile was isolated only from the raw meat preparation (pork sausage). All the isolated strains were toxigenic and susceptible to all the tested antibiotics. Strains isolated from carcass samples displayed $\mathrm{A}+\mathrm{B}+\mathrm{CDTa}+\mathrm{CDTb}+$ profile, were toxinotype IV and belonged to the same ribotype arbitrary named TV93, while the one isolated from food samples displayed A+B+CDTa$\mathrm{CDTb}$ - profile and it was not possible to determine ribotype and toxinotype, because it was lost after freeze storage. It was concluded that the prevalence of $C$. difficile in the pork supply chain is very low.
\end{abstract}

Keywords: Clostridioides difficile; pig carcasses; pork products; food safety; real-time PCR; ribotype; MALDI-TOF; toxin genes; emerging foodborne pathogens; community-acquired CDI

\section{Introduction}

Clostridioides difficile (previously known as Clostridium difficile) [1] is an anaerobic, spore-forming bacterium and it is considered one of the main causes of nosocomial diarrhoea in hospitalized patients after antibiotic treatment [2].

In the last decade, the incidence and severity of $C$. difficile infections (CDIs) in humans have been increasing due partly to the spread of hypervirulent strains [3]. Recently community-associated infections have been described and CDI is becoming a widespread cause of diarrhea in younger individuals and in populations lacking traditional risk factors, such as hospitalization and antibiotic treatment [4]. Recent data from North America and Europe suggest that $20 \%-27 \%$ of all CDI cases are community-acquired, with an incidence of 20-30 per 100,000 population [5-7]. The Italian rate of CDI, including the number of community-acquired outbreaks, is not definitively assessed because of the fragmented nature of the data available in the literature [8].

This increasing incidence has led to the investigation of other possible sources of C. difficile acquisition, including the ingestion of contaminated food [9].C. difficile has 
been reported in farm animals $[10,11]$ and in different food products, including those of porcine origin [12-15]. Recent studies have focused on pigs and cattle as C. difficile carriers, suggesting the possibility of carcass contamination during the slaughter process and a potential food safety issue [16-18]. Data describing the prevalence of C. difficile on pig carcasses at slaughterhouses show significant differences related to the geographical contest. Concerning the European background, a Belgian study reported a prevalence of 7\% [18], while, in other world countries, in particular in America and Asia, the contamination rate is higher and it ranges from $8 \%$ to $30 \%[16,17,19-21]$.

Among food samples $C$. difficile was recently isolated from a variety of meat products, including pork products such as: pork sausages $[15,16,22,23]$, ground pork samples $[14,15,21,23,24]$ and ready-to-eat pork products [23], reinforcing the hypothesis of an emerging foodborne pathogen.

PCR-ribotype 078 (RT-078) has been commonly isolated in food products and food animals and some authors consider this ribotypeas potentially involved in foodborne transmission to humans [23,25-29]. This ribotypeis often found in community-acquired infections and it is among the ten most frequently isolated ribotypes in European populations [30]. RT-078 is the most common ribotype in pigs, cattle and horses worldwide [31] and in a recent study performed in Central Italy, it was detected in dairy and beef cattle farms [32]. In the same study, RT-126 turned out to be the most commonly isolated ribotype in calves [32]. The prevalence of this ribotype in humans is variable, ranging from $3 \%$ in a European survey [33] to 34.4\% in Spain [34]. In a different study conducted, in hospitals of Central Italy, this ribotype was also recovered from a hospital food (lettuce) and it was the second most frequently isolated ribotype between human cases of CDI recorded in the same facility [35].

The aim of this study was to evaluate the presence of $C$. difficile on pig carcasses at the slaughterhouse and in pork products in Central Italy. C. difficile isolates were characterized and compared to the main PCR-ribotypes circulating in the same area.

\section{Materials and Methods}

\subsection{Samples Collection}

Between January 2019 and September 2020, 179 carcass samples have been collected from 5 pig slaughterhouses located in Central Italy (Umbria and Marche regions). In particular, three slaughterhouses were classified as small-sized (capacity of $<5000$ animals per year) and 2 as medium-sized (capacity of $>5000$ to $<50000$ animals per year). The animal sample was calculated to estimate prevalence with $95 \%$ confidence interval (CI) and $5 \%$ desired absolute precision, considering a $15 \%$ expected prevalence, on the basis of previous investigations $[18,19]$. Four different points (ham, basin, sternum and forelimb) were swabbed using a single hydrated sponge (Solar-cult Pre-moistened Sponges-Solar Biologicals Inc, Ogdensburg, NY, USA) [18], the samples were stored at $4{ }^{\circ} \mathrm{C}$ and processed within $24-48 \mathrm{~h}$. This carcass sampling method was defined according to thatpreviously reported by Rodriguez et al., 2013 [18].

Pork products were collected from samples submitted to our laboratories for routine diagnosis. They included raw meat preparations (pork sausages) and ready-to-eat food samples (salami, spreadable salami, cured sausages, bacon, cured pork cheek, cured ham, cured pork shoulder and cured pork lean sirloin).

\subsection{Enrichment and Real-Time PCR Screening}

Carcass sponges were put into $50 \mathrm{~mL}$ of Taurocholate Cefoxitin Cycloserine Fructose Broth (TCCFB) (Ethanol 96\% - Sigma-Aldrich Corporation, St. Louis, MO, USA); C. difficile selective supplement-Oxoid Limited, Basingstoke, UK; D-fructose-SigmaAldrich Corporation, St. Louis, MO, USA; monobasic potassium phosphate-Sigma-Aldrich Corporation, St. Louis, MO, USA; proteose peptone-Biolife Italiana s.r.l., Milan, IT; neutral red-Sigma-Aldrich Corporation, St. Louis, MO, USA; sodium phosphate dibasic - Chem-lab, Zedelgem, Belgium; sodium taurocholate hydrate-Sigma-Aldrich Corporation, St. Louis, 
MO, USA) and incubated in anaerobic jars (2.5 L AnaeroJar, AG0025 with AnaeroGen 2.5 L, AN0025, Oxoid Limited, Basingstoke, UK) at $37^{\circ} \mathrm{C}$ for 12 days [18].

Ten grams of each food sample was added to $90 \mathrm{~mL}$ of $C$. difficile Moxalactam Norfloxacin Broth (CDMNB) (CDMN selective supplement-Oxoid Limited, Basingstoke, UK; D-fructose-Sigma-Aldrich Corporation, St. Louis, MO, USA; magnesium sulfate heptahydrate-Merck Millipore, Burlington, MA, USA; monobasic potassium phosphateSigma-Aldrich Corporation, St. Louis, MO, USA; proteose peptone-Biolife Italiana srl, Milan, Italy; defibrinated horse blood-Allevamento Blood di Fiastra Maddalena, Teramo, Italy; sodium chloride-Sigma-Aldrich Corporation, St. Louis, MO, USA; sodium phosphate dibasic - Chem-lab, Zedelgem, Belgium; sodium taurocholate hydrate-Sigma-Aldrich Corporation, St. Louis, MO, USA) and incubated in anaerobic jars at $37^{\circ} \mathrm{C}$ for 12 days [36].

After the incubation, $1 \mathrm{~mL}$ of each sample was used for DNA extraction using 6\% Chelex-100 sodium form (Sigma-Aldrich Corporation, St. Louis, MO, USA).

In order to detect $C$. difficile, a real-time PCR screening was performed, amplifying a species-specific internal fragment of the triose phosphate isomerase (tpi) housekeeping gene, using the primers tpi- $F$ [5'-AAAGAAGCTACTAAGGGTACAAA-3'] and tpi- $R$ [5'-CATAATATTGGGTCTATTCCTAC-3'], described by Lemee et al. [37]. The PCR reaction was carried out in $20 \mu \mathrm{L}$ of final mix containing: $2 \mu \mathrm{L}$ of DNA, $10 \mu \mathrm{L}$ of a ready-to-use mix of Taq polymerase and SYBR Green (KAPA SYBR FAST qPCR Master Mix (2X) Universal; KK 4601, Kapa Biosystems, Wilmington, MA, USA), $450 \mathrm{nM}$ of each primer, forward and reverse, $1 \mathrm{nM}$ of ROX and water for molecular biology.Amplification was performed on Stratagene Mx3005P instrument (Agilent Technologies, Santa Clara, CA, USA) under the following conditions, as described by Morales et al. [38] and according to the Master Mix manufacturer's instructions: initial denaturation at $95^{\circ} \mathrm{C}$ for $3 \mathrm{~min}, 40$ cycles at $95^{\circ} \mathrm{C}$ for $3 \mathrm{~s}$ and $60^{\circ} \mathrm{C}$ for $30 \mathrm{~s}$, with a final melting curve ranging from $65^{\circ} \mathrm{C}$ to $95^{\circ} \mathrm{C}$. A negative control, consisting of water for molecular biology and a positive control, represented by a reference C. difficile strain (CDC20120296-Microbiologics, St. Cloud, MN, USA) were also set up. Under these conditions, the melting temperature of the tpi amplicon was $78^{\circ} \mathrm{C}$, whereas that of the primer dimers was $71^{\circ} \mathrm{C}$.

\subsection{Isolation and Identification}

The positive broth cultures were alcohol shocked by mixing $2 \mathrm{~mL}$ of broth with 96\% ethanol (1:1 v/v) (Sigma-Aldrich Corporation, St. Louis, MO, USA) for $30 \mathrm{~min}$ at room temperature. After centrifugation $(3800 \times g$ for $10 \mathrm{~min}$ ) the sediment was streaked onto Taurocholate Cefoxitin Cycloserine Fructose Agar (TCCFA) (TCCFB additioned with agar-Biolife Italiana s.r.l., Milan, Italy) for carcass sample [18] and C. difficile Moxalactam Norfloxacin Agar (CDMNA) (CDMN selective supplement-Oxoid Limited, Basingstoke, UK; C. difficile agar base-Oxoid Limited, Basingstoke, UK; defibrinated horse bloodAllevamento Blood di Fiastra Maddalena, Teramo, Italy) for food samples [36] and incubated for $48 \mathrm{~h}$ in anaerobic jars. Suspected colonies (rhizoid colonies, non-hemolytic) were presumptively identified on the basis of Gram and latex agglutination test (C. difficile test kit-Oxoid Limited, Basingstoke, UK) and then confirmed using a MALDI-TOF MS instrument (Bruker Daltonics, Bremen, Germany) with Microflex LT Smart Biotyper and Flex Control Biotyper 3.4 software (Bruker Daltonics, Bremen, Germany). Briefly, the formic acid extraction technique was performed for each isolate by adding one or two colonies to a microcentrifuge tube containing $300 \mu \mathrm{L}$ of HPLC grade deionized water. The suspension was mixed thoroughly by pipetting, and $900 \mu \mathrm{L}$ of absolute ethanol was further added and mixed thoroughly again. After a centrifugation of $2 \mathrm{~min}$ at $3000 \times g$, the supernatant was discarded and $50 \mu \mathrm{L}$ of $70 \%$ formic acid was added to the pellet and vortexed. Fifty $\mu \mathrm{L} f$ $100 \%$ acetonitrile was added and mixed, followed by a 2 min centrifugation at $3000 \times g$. One $\mu \mathrm{L}$ of the supernatant was added to the target slide and dried at room temperature. One $\mu \mathrm{L}$ of the HCCA matrix was applied on the sample spot and dried at room temperature. 


\subsection{Strains Characterization}

All the confirmed strains were screened by two different multiplex end-point PCRs: one for $t p i$ and the toxin genes $t c d A$ and $t c d B$ [37] and the other for the binary toxin genes $c d t A$ and $c d t B$ [39], using the primers described in literature.

DNA extraction was performed on 48 -h blood agar cultures, by boiling at $100{ }^{\circ} \mathrm{C}$ for $5 \mathrm{~min}$ and subsequently frozen at $-20^{\circ} \mathrm{C}$ for $10 \mathrm{~min}$, the mixture was then centrifuged at $3000 \times g$ for $10 \mathrm{~min}[40]$.

The PCR reactions were performed on Eppendorf Mastercycler instrument (Eppendorf s.r.l., Milan, Italy) according to the conditions given by Lamee et al., 2004 [37], Doosti et al., 2014 [39] and to the Master Mix manufacturer's instructions. The first multiplex PCR reaction $(t c d A, t c d B$ and $t p i)$ [37] was carried out in $50 \mu \mathrm{L}$ of final mixture containing: $2 \mu \mathrm{L}$ of DNA, $25 \mu \mathrm{L}$ of HotStarTaqMM $2 X$ (Qiagen, Hilden, Germany) $2 \mathrm{mM}$ $\mathrm{MgCl}_{2}$ (Qiagen, Hilden, Germany), $0.5 \mu \mathrm{M}$ of tpiF and tpiR primers and $1 \mu \mathrm{M}$ of the other primers. The conditions used were: initial denaturation at $95^{\circ} \mathrm{C}$ for $15 \mathrm{~min}, 11$ cycles at $95^{\circ} \mathrm{C}$ for $30 \mathrm{~s}, 65-55^{\circ} \mathrm{C}$ (scaling one degree each cycle) for $30 \mathrm{~s}, 72{ }^{\circ} \mathrm{C}$ for $30 \mathrm{~s}, 29$ cycles at $95^{\circ} \mathrm{C}$ for $30 \mathrm{~s}, 55^{\circ} \mathrm{C}$ for $30 \mathrm{~s}, 72{ }^{\circ} \mathrm{C}$ for $30 \mathrm{~s}$ and a final extension step at $72{ }^{\circ} \mathrm{C}$ for $5 \mathrm{~min}$. The second one ( $c d t A$ and $c d t B$ ) [28] was carried out in $50 \mu \mathrm{L}$ of final mix containing: $2 \mu \mathrm{L}$ of DNA, $25 \mu \mathrm{L}$ of HotStarTaqMM 2X (Qiagen, Hilden, Germany), $6 \mathrm{mM} \mathrm{MgCl}_{2}$ (Qiagen, Hilden, Germany), $1 \mu \mathrm{M}$ of each primer. The reaction was performed under the following conditions: initial denaturation at $95^{\circ} \mathrm{C}$ for $15 \mathrm{~min}, 40$ cycles at $94{ }^{\circ} \mathrm{C}$ for $60 \mathrm{~s}, 59^{\circ} \mathrm{C}$ for $60 \mathrm{~s}, 72{ }^{\circ} \mathrm{C}$ for $60 \mathrm{~s}$ and a final extension step at $72{ }^{\circ} \mathrm{C}$ for $7 \mathrm{~min}$. To check each PCR session a negative control, consisting of water for molecular biology and a positive control, represented by a reference $C$. difficile strain (CDC20120296-Microbiologics, St. Cloud, MN, USA) were set up. The PCR products were uploaded in the QIAxcel System Instrument (Qiagen, Hilden, Germany), an automated capillary electrophoresis device and analyzed by the QIAxcelScreengel 1.4.0 software (Qiagen, Hilden, Germany) for size determination of the detected fragments.

Toxinotyping and PCR-ribotyping were performed according to the protocol described by Rupnik et al. [41,42] and Bidet et al. [43], respectively. For PCR-ribotyping, the profile of the testes strains were compared to the predominant PCR-ribotypes circulating in Europe (RT-001, RT-002, RT-003, RT-005, RT-010, RT-012, RT-016, RT-017, RT-018, RT-014/020, RT-027, RT-031/1, RT-033, RT-050, RT-056, RT-070, RT-078, RT-081, RT-103, RT-126, RT-127, RT-150, RT-205, RT-403, RT-439, RT-449, RT-548, RT-592, RT-614). Isolates not showing any matches were named using an internal nomenclature (Treviso, TV and number).

\subsection{Antimicrobial Susceptibility Testing}

Minimum inhibitory concentrations (MICs) were determined for clindamycin (CLI), metronidazole (MTZ), moxifloxacin (MXF) and vancomycin (VAN) using Etest strips (CLI,509518-MTZ,530018-MXF,529018-VAN,525518 - bioMèrieux, Marcy-L'Étoile, France), following the manufacturer's technical guide. Bacterial suspensions were streaked on Brucella Blood Agar (Brucella Agar-Becton Dickinson, Franklin Lakes, NJ, USA; HeminSigma-Aldrich Corporation, St. Louis, MO, USA; defibrinated horse blood-Allevamento Blood di Fiastra Maddalena, Teramo, Italy) and incubated for $48 \mathrm{~h}$ in anaerobic jars. MICs were recorded after the incubation and analyzed according to the epidemiological cut-off (ECOFF) (EUCAST, https://www.eucast.org, accessed on 15 July 2020). Isolates with MIC values $>2 \mathrm{mg} / \mathrm{L}$ for MTZ and VAN, $>4 \mathrm{mg} / \mathrm{L}$ for MXF and $>16 \mathrm{mg} / \mathrm{L}$ for CLI were considered with reduced antimicrobial susceptibility. Furthermore, Bacteroides fragilis ATCC 25285 was included as a quality control strain.

\section{Results}

\subsection{Prevalence of C. Difficile in Carcass Samples and Food Samples}

A total of 179 pig carcass samples were analyzed, PCR screening was positive for $4 / 179$ samples $(2.3 \%)$ and C. difficile was isolated from all the positive ones. The isolates obtained were called: CDS1, CDS2, CDS3, CDS4. 
Concerning food samples, a total of 216 pork products were tested. They included 74 raw meat preparations (pork sausages) and 142 ready-to-eat food samples made by cured raw meat. The real-time PCR screening was positive for $1 / 74$ raw meat preparation $(1.35 \%)$ and for $1 / 142$ ready-to-eat food samples $(0.7 \%)$ C. difficile was isolated only from the raw meat preparation (pork sausage) and the isolate was called CDF1. Strain isolation from the ready-to-eat food sample (salami) resulted negative, probably due to the low level of contamination or to the presence of the bacterium in a non-viable form (Table 1).

Table 1. Prevalence of $C$. difficile in pork products (raw meat preparations and ready-to-eat products).

\begin{tabular}{cccc}
\hline Sample Types & $\begin{array}{c}\text { No. } \\
\text { Tested Samples }\end{array}$ & $\begin{array}{c}\text { No. (\%) Positive Samples } \\
\text { (Real-Time PCR) }\end{array}$ & $\begin{array}{c}\text { No. (\%) C. difficile } \\
\text { Isolates }\end{array}$ \\
\hline Sausages & 74 & $1(1.4 \%)$ & $1(1.4 \%)$ \\
\hline Total raw meat preparations & 74 & $1(1.4 \%)$ & $1(1.4 \%)$ \\
\hline Salami & 64 & $1(1.6 \%)$ & $0(0 \%)$ \\
Spreadable salami & 27 & $0(0 \%)$ & $0(0 \%)$ \\
Cured sausage & 25 & $0(0 \%)$ & $0(0 \%)$ \\
Bacon & 7 & $0(0 \%)$ & $0(0 \%)$ \\
Cured pork's cheek & 1 & $0(0 \%)$ & $0(0 \%)$ \\
Cured ham & 10 & $0(0 \%)$ & $0(0 \%)$ \\
Cured pork's shoulder & 4 & $0(0 \%)$ & $0(0 \%)$ \\
Cured pork's lean sirloin & 4 & $0(0 \%)$ & $0(0 \%)$ \\
\hline Total ready-to-eat & 142 & $1(0.7 \%)$ & \\
pork products & & & \\
\hline
\end{tabular}

The colonies were identified as $C$. difficile by MALDI-TOF MS. Except for CDF1, all the isolates had a high-confidence identification spectral score (Table 2) and high consistency interpretation (A), since the same species was identified as the second- and third-best match. The strains were further confirmed through molecular investigations.

Table 2. Identification spectral score of MALDI-TOF MS of C. difficile.

\begin{tabular}{cc}
\hline Isolate ID & Score \\
\hline CDS1 & 2.18 \\
CDS2 & 2.23 \\
CDS3 & 2.16 \\
CDS4 & 2.19 \\
CDF1 & 1.90 \\
\hline
\end{tabular}

\subsection{Strains Characterization and Antimicrobial Susceptibility}

All the isolated strains were confirmed as $C$. difficile due to the presence of tpi (Figure 1). CDS1, CDS2, CDS3, CDS4 (isolated from carcass sponges) belonged to PCR-ribotype TV93, toxinotype IV and displayed $\mathrm{A}^{+} \mathrm{B}^{+} \mathrm{CDTa}^{+} \mathrm{CDTb}^{+}$profile (Figure 1, Table 3), $\mathrm{CDF}$ (isolated from pork sausages) displayed $\mathrm{A}^{+} \mathrm{B}^{+} \mathrm{CDTa}{ }^{-} \mathrm{CDTb}^{-}$profile (Figure 1, Table 3 ), while ribotype and toxinotype determination was not possible, because it was lost after the storage procedure. The isolates were susceptible to all the antibiotics tested (Table 3). 

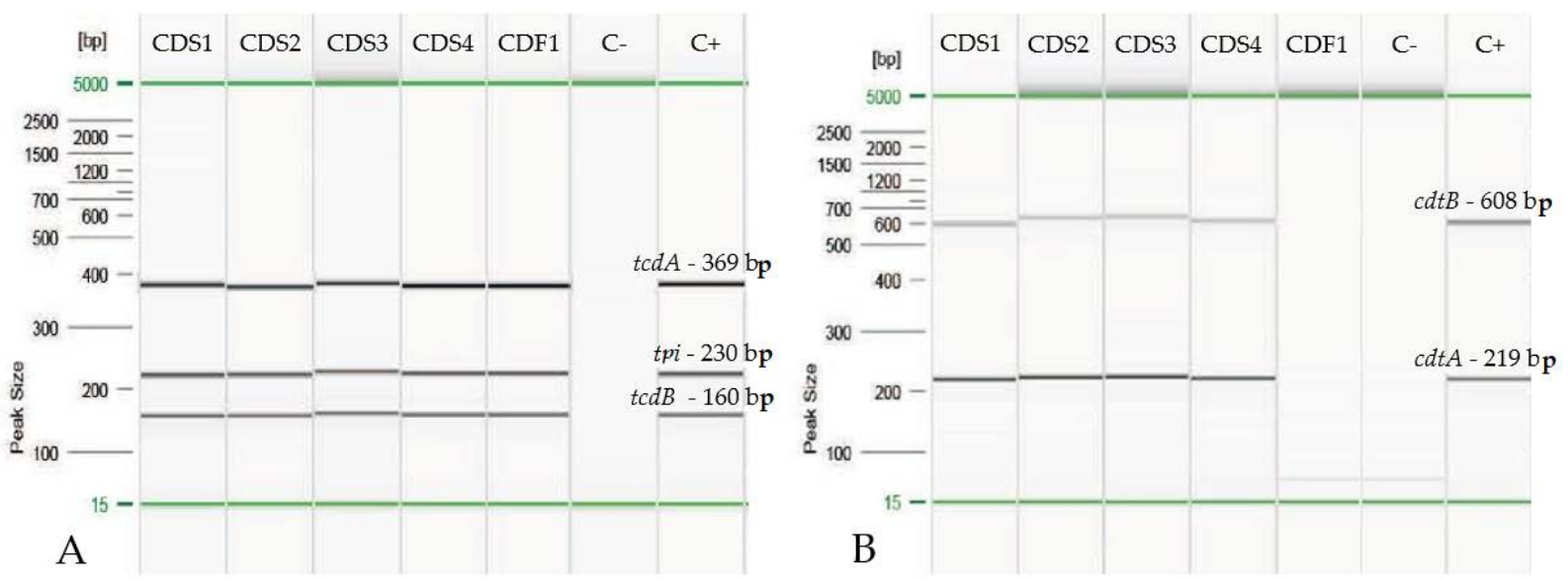

Figure 1. Capillary electrophoresis results (QIAxcelScreengel 1.4.0 software). Multiplex PCR for detection of $t p i, t c d A$ and $t c d B$ (A). Multiplex PCR for detection of $c d t A$ and $c d t B$ (B).

Table 3. Ribotype, toxinotype and MICs values (mg/L) of C. difficile isolates.

\begin{tabular}{|c|c|c|c|c|c|c|c|c|c|c|c|}
\hline \multirow[t]{2}{*}{ Isolate ID } & \multirow{2}{*}{$\begin{array}{l}\text { Source of } \\
\text { isolation }\end{array}$} & \multirow[t]{2}{*}{ Ribotype } & \multirow[t]{2}{*}{ Toxinotype } & \multicolumn{4}{|c|}{$\begin{array}{l}\text { Detection of Toxin } \\
\text { Genes by PCR }\end{array}$} & \multicolumn{4}{|c|}{ Antimicrobials $^{1}$} \\
\hline & & & & $\operatorname{tcd} A$ & tcdB & $\operatorname{cdtA}$ & cdtB & CLI & MTZ & VAN & MXF \\
\hline CDS1 & Carcass sponge & TV93 $^{2}$ & IV & + & + & + & + & 3 & 0.25 & 1 & 0.5 \\
\hline CDS2 & Carcass sponge & ${\text { TV } 93^{2}}^{2}$ & IV & + & + & + & + & 1 & 0.125 & 0.75 & 0.38 \\
\hline CDS3 & Carcass sponge & TV93 $^{2}$ & IV & + & + & + & + & 2 & 0.19 & 0.75 & 0.5 \\
\hline CDS4 & Carcass sponge & ${\text { TV } 93^{2}}^{2}$ & IV & + & + & + & + & 1 & 0.125 & 1 & 0.38 \\
\hline CDF1 & Pork sausage & $\mathrm{NT}^{3}$ & $\mathrm{NT}^{3}$ & + & + & - & - & 2 & 0.19 & 0.75 & 0.5 \\
\hline
\end{tabular}

${ }^{1}$ CLI = Clindamycin, MXF = Moxifloxacin, MTZ = Metronidazole, VAN = Vancomycin. ${ }^{2}$ TV stands for internal nomenclature (Treviso, $\mathrm{TV}$ and number). ${ }^{3} \mathrm{NT}=$ not tested.

\section{Discussion}

The present study determined the prevalence of $C$. difficile in pig carcasses and in pork products in Central Italy.

C. difficile was recovered from four carcasses (4 out of $179-2.2 \%$ ) and all the positive samples came from the same slaughterhouse (Umbria region). The isolated strains belonged to a ribotype that did not match the reference strains available in the laboratory, nor with the human strains tested in previous studies conducted in the same area [35]. Our results agree with what was observed in a previous European study on pig carcasses [18], while it significantly differs from data obtained in other countries $[16,17,19]$, where higher prevalence is reported (15-30\%). This suggests that in Europe the prevalence of $C$. difficile in pig carcasses at slaughterhouses is very low.

Molecular screening of food samples showed a total prevalence of $C$. difficile of $0.9 \%$ ( 2 out of 216), in particular: 1.4\% (1 out of 74) for raw products to be consumed cooked and $0.7 \%$ (1 out of 142 ) for ready-to-eat products. The only positive sample, from which it was possible to isolate $C$. difficile, was the raw meat preparation (pork sausages). In the cured meat product (salami), isolation was not possible, probably due to a very low concentration of the microorganism or to the presence of the germ in a no longer viable form. As regards pork sausages, the prevalence we observed was slightly lower than a previous European study (5 of 107 uncooked pork samples-4.7\%) [15] and an American study, where the prevalence of $C$. difficile in pork sausages was 4.9\% (2 of 41) [22]. Almost all the bibliographic data, about food of swine origin, concerns raw products to be consumed cooked and not ready-to-eat products. An American study, with a lower sampling size, detected higher prevalence (from $14.3 \%$ to $62.5 \%$ ) than what we observed in different kinds of ready-to-eat pork products [23]. Some studies, instead, completely failed to detect $C$. difficile in pork and pork products in The Netherlands, Switzerland, France, and Sweden [44-47]. Differences in prevalence observed between our study and previous studies could be due to different 
sampling methods and isolation conditions, making it difficult to compare results and to give an objective evidence for foodborne transmission. As already reported for Salmonella spp. in pig carcasses [48], a harmonized and integrated approach along the food chain and across different countries would be desirable to reduce the presence of these pathogens in pork and pork products.

As regards antimicrobial susceptibility, in our study, the isolates were fully susceptible to all the antimicrobials tested, as already observed by Rodriguez el al. [15] in strains not associated with any reference ribotypes. In pork meat, MXF resistance has been previously reported for $C$. difficile isolates belonging to PCR-ribotype 078 [15]. In a prospective study of CDIs in Europe, the same resistance was observed in $37.5 \%$ of the clinical strains circulating in hospitals [49]. Low susceptibility to CLI in C. difficile pork meat isolates belonging to PCR-ribotype 027 has been observed [23], and this may not be due to the widespread use of tylosin, erythromycin, virginiamycin, and lincomycin in food animals and the consequent potential for selection of macrolide-lincosamide-streptogramin resistance [50]. In human therapy, VAN together with MTZ are the recommended first-line antimicrobials for the treatment of CDIs [51], although one of the most important risk factors for the disease is exposure to antibiotics [52,53] and there is an increasing concern about the emergence of antibiotic resistance resulting in treatment failure [54]. A valuable alternative could be potentially represented by the use of natural antimicrobials, especially those extracted from food industry by-products, along the food production chain to inhibit or limit microbial growth [55-58]. This approach would allow for the pursuing of both public health protection and environmental sustainability.

In summary, our data suggest that $C$. difficile occurs as a low-level contaminant in the pork supply chain. Despite the low number of isolated strains, all of them carried virulence genes capable of causing diarrhea and colitis in humans, in particular in vulnerable groups that should be advised to avoid potentially contaminated products. Additional studies are needed to characterize risks posed by this organism in the human food supply and its clinical relevance.

Author Contributions: Conceptualization, S.P. and E.D.R.M.; methodology, C.L., S.P., S.F. and I.D.; validation, S.F. and E.D.R.M.; formal analysis, C.L., S.P., A.L. and I.D.; investigation, A.L., G.B., A.P. and S.F.; resources, G.B. and A.P.; data curation, C.L. and S.P.; writing-original draft preparation, C.L.; writing—review and editing, S.P. and R.R.; visualization, R.R.; supervision, S.F. and E.D.R.M.; project administration, S.F. and E.D.R.M.; funding acquisition, S.P. and S.F. All authors have read and agreed to the published version of the manuscript.

Funding: This research was funded by the Italian Ministry of Health, grant number RC0122018CUP D96C18000760005 “Valutazione della prevalenza di Clostridium difficile sulle carcasse suine e lungo la filiera dei salumi nel territorio Umbro-Marchigiano attraverso lo sviluppo di metodi rapidi per la rilevazione".

Institutional Review Board Statement: Not applicable.

Informed Consent Statement: Not applicable.

Data Availability Statement: Data are available from the authors.

Acknowledgments: The authors would like to thank Stefania Scuota (Istituto Zooprofilattico Sperimentale dell'Umbria e delle Marche "Togo Rosati") for her significant support in the organization of the project and Luca Budelli (Servizio di Igiene degli Alimenti di Origine Animale-USL Umbria 1) and Valentina Gentili and Simonetta Ruggeri (Servizio di Igiene degli Alimenti di Origine Animale-ASUR Marche AV 4 Fermo) for the samples collection.

Conflicts of Interest: The authors declare no conflict of interest. 


\section{References}

1. Lawson, P.A.; Citron, D.M.; Tyrrell, K.L.; Finegold, S.M. Reclassification of Clostridium difficile as Clostridioides difficile (Hall and O’Toole 1935) Prevot 1938. Anaerobe 2016, 40, 95-99. [CrossRef]

2. McDonald, L.C.; Owings, M.; Jernigan, D.B. Clostridium difficile infection in patients discharged from US short-stay hospitals, 1996-2003. Emerg. Infect. Dis. 2006, 12, 409-415. [CrossRef]

3. Freeman, J.; Bauer, M.P.; Baines, S.D.; Corver, J.; Fawley, W.N.; Goorhuis, B.; Kuijper, E.J.; Wilcox, M.H. The Changing Epidemiology of Clostridium difficile Infections. Clin. Microbiol. Rev. 2010, 23, 529-549. [CrossRef]

4. Khanna, S.; Pardi, D.S.; Aronson, S.L.; Kammer, P.P.; Orenstein, R.; St Sauver, J.L.; Harmsen, W.S.; Zinsmeister, A.R. The epidemiology of community-acquired Clostridium difficile infection: A population-based study. Am. J. Gastroenterol. 2012, 107, 89-95. [CrossRef] [PubMed]

5. Wilcox, M.H.; Mooney, L.; Bendall, R.; Settle, C.D.; Fawley, W.N. A case-control study of community-associated Clostridium difficile infection. J. Antimicrob. Chemother. 2008, 62, 388-396. [CrossRef] [PubMed]

6. Kutty, P.K.; Woods, C.W.; Sena, A.C.; Benoit, S.R.; Naggie, S.; Frederick, J.; Evans, S.; Engel, J.; McDonald, L.C. Risk factors for and estimated incidence of community-associated Clostridium difficile infection, North Carolina, USA. Emerg. Infect. Dis. 2010, 16, 197-204. [CrossRef]

7. Lambert, P.J.; Dyck, M.; Thompson, L.H.; Hammond, G.W. Population-based surveillance of Clostridium difficile infection in Manitoba, Canada, by using interim surveillance definitions. Infect. Control. Hosp. Epidemiol. 2009, 30, 945-951. [CrossRef]

8. Visconti, V.; Brunetti, G.; Cuomo, M.R.; Giordano, A.; Raponi, G. Nosocomial-acquired and community-onset Clostridium difficile infection at an academic hospital in Italy: Epidemiology, recurrences and toxin genes distribution. J. Infect. Chemother. 2017, 23, 763-768. [CrossRef] [PubMed]

9. Janezic, S.; Ocepek, M.; Zidaric, V.; Rupnik, M. Clostridium difficile genotypes other than ribotype 078 that are prevalent among human, animal and environmental isolates. BMC Microbiol. 2012, 12, 48. [CrossRef] [PubMed]

10. Rodriguez-Palacios, A.; Staempfli, H.R.; Duffield, T.; Peregrine, A.S.; Trotz-Williams, L.A.; Arroyo, L.G.; Brazier, J.S. Clostridium difficile PCR ribotypes in calves, Canada. Emerg. Infect. Dis. 2006, 12, 1730-1736. [CrossRef]

11. Songer, J.G.; Anderson, M.A. Clostridium difficile: An important pathogen of food animals. Anaerobe 2006, 12, 1-4. [CrossRef]

12. Al Saif, N.; Braziers, J.S. The distribution of Clostridium difficile in the environment of South Wales. J. Med. Microbiol. 1996, $45,133-137$. [CrossRef]

13. Bakri, M.M.; Brown, D.J.; Butcher, J.P.; Sutherland, A.D. Clostridium difficile in ready-to-eat salads, Scotland. Emerg. Infect. Dis. 2009, 15, 817-818. [CrossRef]

14. Metcalf, D.; Reid-Smith, R.J.; Avery, B.P.; Weese, J.S. Prevalence of Clostridium difficile in retail pork. Can. Vet. J. 2010, 51, 873-876. [PubMed]

15. Rodriguez, C.; Taminiau, B.; Avesani, V.; Van Broeck, J.; Dalmée, M.; Daube, G. Multilocus sequence typing analysis and antibiotic resistance of Clostridium difficile strains isolated from retail meat and humans in Belgium. Food Microbiol. 2014, 42, 166-171. [CrossRef]

16. Harvey, R.B.; Norman, K.N.; Andrews, K.; Norby, B.; Hume, M.E.; Scanlan, C.M.; Hardin, M.D.; Scott, H.M. Clostridium difficile in retail meat and processing plants in Texas. J. Vet. Diagn. Investig. 2011, 23, 807-811. [CrossRef] [PubMed]

17. Hawken, P.; Weese, J.S.; Friendship, R.; Warriner, K. Longitudinal study of Clostridium difficile and Methicillin-resistant Staphylococcus aureus associated with pigs from weaning through to the end processing. J. Food Prot. 2013, 76, 624-630. [CrossRef] [PubMed]

18. Rodriguez, C.; Avesani, V.; Van Broeck, J.; Taminiau, B.; Delmee, M.; Daube, G. Presence of Clostridium difficile in pigs and cattle intestinal contents and carcass contamination at the slaughterhouse in Belgium. Int. J. Food Microbiol. 2013, 166, 256-262. [CrossRef] [PubMed]

19. Wu, Y.C.; Chen, C.M.; Kuo, C.J.; Lee, J.J.; Chen, P.C.; Chang, Y.C.; Chen, T.H. Prevalence and molecular characterization of Clostridium difficile isolates from a pig slaughterhouse, pork, and humans in Taiwan. Int. J. Food Microbiol. 2017, 242, 37-44. [CrossRef] [PubMed]

20. Rodriguez-Palacios, A.; Reid-Smith, R.J.; Staempfli, H.R.; Daignault, D.; Janecko, N.; Avery, B.P.; Martin, H.; Thompson, A.D.; McDonald, L.C.; Limbago, B.; et al. Possibility of seasonality of Clostridium difficile in retail meat, Canada. Emerg. Infect. Dis. 2009, 15, 802-805. [CrossRef]

21. Weese, J.S.; Avery, B.P.; Rousseau, J.; Reid-Smith, R.J. Detection and enumeration of Clostridium difficile spores in retail beef and pork. Appl. Environ. Microbiol. 2009, 75, 5009-5011. [CrossRef]

22. Curry, S.R.; Marsh, J.W.; Schlackman, J.L.; Harrison, L.H. Prevalence of Clostridium difficile in uncooked ground meat products from Pittsburgh, Pennsylvania. Appl. Environ. Microbiol. 2012, 78, 4183-4186. [CrossRef]

23. Visser, M.; Sephri, S.; Olson, N.; Mulvey, M.R.; Alfa, M.J. Detection of Clostridium difficile in retail ground meat products in Manitoba. Can. J. Infect. Dis. Med. Microbiol. 2012, 23, 28-30. [CrossRef]

24. Songer, J.G.; Trinh, H.T.; Killgore, G.E.; Thompson, A.D.; McDonald, L.C.; Limbago, B.M. Clostridium difficile in retail meat products, USA, 2007. Emerg. Infect. Dis. 2009, 15, 819-821. [CrossRef]

25. Debast, S.B.V.L.L.A.; Ghoorhuis, A.; Harmanus, C.; Kujiper, E.J.; Bergwerff, A.A. Clostridium difficile PCR ribotype 078 toxinotype $\mathrm{V}$ found in diarrhoeal pigs identical to isolates from affected humans. Environ. Microbiol. 2009, 11, 505-511. [CrossRef] 
26. Goorhuis, A.; Debast, S.B.; van Leengoed, L.A.; Harmanus, C.; Notermans, D.W.; Bergwerff, A.A.; Kuijper, E.J. Clostridium difficile PCR ribotype 078: An emerging strain in humans and in pigs? J. Clin. Microbiol. 2008, 46, 1157-1158. [CrossRef] [PubMed]

27. Gould, L.H.; Limbago, B. Clostridium difficile in food and domestic animals: A new foodborne pathogen? Clin. Infect. Dis. 2010, 51, 577-582. [CrossRef] [PubMed]

28. Jhung, M.A.; Thompson, A.D.; Killgore, G.E.; Zukowski, W.E.; Songer, G.; Warny, M.; Johnson, S.; Gerding, D.N.; McDonald, L.C.; Limbago, B.M. Toxinotype V Clostridium difficile in humans and food animals. Emerg. Infect. Dis. 2008, 14, 1039-1045. [CrossRef]

29. Weese, J.S.; Reid-Smith, R.J.; Avery, B.P.; Rousseau, J. Detection and characterization of Clostridium difficile in retail chicken. Lett. Appl. Microbiol. 2010, 50, 362-365. [CrossRef]

30. Dingle, K.E.; Didelot, X.; Phuong Quan, T.; Eyre, D.W.; Stoesser, N.; Marwick, C.A.; Coia, J.; Brown, D.; Buchanan, S.; Ijaz, U.Z. A Role for Tetracycline Selection in Recent Evolution of Agriculture-Associated Clostridium difficile PCR Ribotype 078. MBio 2019, 10, e2790-18. [CrossRef] [PubMed]

31. Kachrimanidou, M.; Tzika, E.; Filioussis, G. Clostridioides (Clostridium) difficile in food-producing animals, horses and household pets: A comprehensive review. Microorganisms 2019, 7, 667. [CrossRef] [PubMed]

32. Blasi, F.; Lovito, C.; Albini, E.; Bano, L.; Dalmonte, G.; Drigo, I.; Maresca, C.; Massacci, F.R.; Orsini, S.; Primavilla, S.; et al. Clostridioides difficile in Calves in Central Italy: Prevalence, Molecular Typing, Antimicrobial Susceptibility and Association with Antibiotic Administration. Animals 2021, 11, 515. [CrossRef] [PubMed]

33. Bauer, M.P.; Notermans, D.W.; Van Benthem, B.H.; Brazier, J.S.; Wilcox, M.H.; Rupnik, M.; Monnet, D.L.; Van Dissel, J.T.; Kuijper, E.J. Clostridium difficile infection in Europe: A hospital-based survey. Lancet 2011, 377, 63-73. [CrossRef]

34. Álvarez-Pérez, S.; Blanco, J.L.; Harmanus, C.; Kuijper, E.; García, M.E. Subtyping and antimicrobial susceptibility of Clostridium difficile PCR ribotype 078/126 isolates of human and animal origin. Vet. Microbiol. 2017, 199, 15-22. [CrossRef]

35. Primavilla, S.; Farneti, S.; Petruzzelli, A.; Drigo, I.; Scuota, S. Contamination of hospital food with Clostridium difficile in Central Italy. Anaerobe 2019, 55, 8-10. [CrossRef]

36. Rodriguez-Palacios, A.; Staempfli, H.R.; Duffield, T.; Weese, J.S. Clostridium difficile in retail ground meat, Canada. Emerg. Infect. Dis. 2007, 13, 485-487. [CrossRef]

37. Lemee, L.; Dhalluin, A.; Testelin, S.; Mattrat, M.A.; Maillard, K.; Lemeland, J.F.; Pons, J.L. Multiplex PCR targeting tpi (Triose Phosphate Isomerase), $t c d A$ (toxin A) and $t c d B$ (toxin B) genes for toxigenic culture of Clostridium difficile. J. Clin. Microbiol. 2004, 42, 5710-5714. [CrossRef]

38. Morales, L.; Rodríguez, C.; Gamboa-Coronado, M.D.M. Molecular detection of Clostridium difficile on inert surfaces from a Costa Rican hospital during and after an outbreak. Am. J. Infect. Control. 2016, 44, 1517-1519. [CrossRef]

39. Doosti, A.; Mokhtari-Farsani, A. Study of the frequency of Clostridium difficiletcdA, $t c d B, c d t A$ and $c d t B$ genes in feces of Calves in south west of Iran. Ann. Clin. Microbiol. Antimicrob. 2014, 5, 13-21.

40. Marcos, P.; Whyte, P.; Rogers, T.; McElroy, M.; Fanning, S.; Frias, J.; Bolton, D. The prevalence of Clostridioides difficile on farms, in abattoirs and in retail foods in Ireland. Food Microbiol. 2021, 98, 103781. [CrossRef] [PubMed]

41. Rupnik, M.; Avesani, V.; Janc, M.; von Eichel-Streiber, C.; Delmée, M. A novel toxinotyping scheme and correlation of toxinotypes with serogroups of Clostridium difficile isolates. J. Clin. Microbiol. 1998, 36, 2240-2247. [CrossRef]

42. Rupnik, M. Clostridium difficile toxinotyping. Methods Mol. Biol. 2010, 646, 67-76.

43. Bidet, P.; Barbut, F.; Lalande, V.; Burghoffer, B.; Petit, J.C. Development of a new PCR ribotyping method for Clostridium difficile based on ribosomal RNA gene sequencing. FEMS Microbiol. Lett. 1999, 175, 261-266. [CrossRef]

44. Bouttier, S.; Barc, M.C.; Felix, B.; Lambert, S.; Collignon, A.; Barbut, F. Clostridium difficile in ground meat, France. Emerg. Infect. Dis. 2010, 16, 733-735. [CrossRef]

45. de Boer, E.; Zwartkruis-Nahuis, A.; Heuvelink, A.E.; Harmanus, C.; Kuijper, E.J. Prevalence of Clostridium difficile in retailed meat in The Netherlands. Int. J. Food Microbiol. 2011, 144, 561-564. [CrossRef]

46. Hofer, E.; Haechler, H.; Frei, R.; Stephan, R. Low occurrence of Clostridium difficile in fecal samples of healthy calves and pigs at slaughter and in minced meat in Switzerland. J. Food Prot. 2010, 73, 973-975. [CrossRef]

47. Von Abercron, S.M.M.; Karlsson, F.; Wigh, G.T.; Wierup, M.; Krovacek, K. Low occurrence of Clostridium difficile in retail ground meat in Sweden. J. Food Prot. 2009, 72, 1732-1734. [CrossRef]

48. Primavilla, S.; Roila, R.; Zicavo, A.; Ortenzi, R.; Branciari, R.; Shtylla Kika, T.; Valiani, A.; Ranucci, D. Salmonella spp. in Pigs laughtered in Small and Medium-Sized Abattoirs in Central Italy: Preliminary Results on Occurrence and Control Strategies. Appl. Sci. 2021, 11, 7600. [CrossRef]

49. Barbut, F.; Mastrantonio, P.; Delmée, M.; Brazier, J.; Kuijper, E.; Poxton, I. Prospective study of Clostridium difficile infections in Europe with phenotypic and genotypic characterisation of the isolates. Clin. Microbiol. Infect. 2007, 13, 1048-1057. [CrossRef]

50. Giguère, S.; Prescott, J.F.; Baggot, J.D.; Walker, R.D.; Dowling, P.M. Antimicrobial Therapy in Veterinary Medicine, 4th ed.; Blackwell Publishers: Ames, IA, USA, 2006; p. 16.

51. Lewis, B.B.; Buffie, C.G.; Carter, R.; Leiner, I.; Toussaint, N.C.; Miller, L.; Gobourne, A.; Ling, L.; Pamer, E. Loss of microbiotamediated colonization resistance to Clostridium difficile infection is greater following oral vancomycin as compared with metronidazole. J. Infect. Dis. 2015, 212, 1656-1665. [CrossRef]

52. Owens, R.C.; Donksey, C.J.; Gaunes, R.P.; Loo, V.G.; Muto, C.A. Antimicrobial-associated risk factors for Clostridium difficile infection. Clin. Infect. Dis. 2008, 46, S19-S31. [CrossRef] 
53. Henrich, T.J.; Krakower, D.; Bitton, A.; Yokoe, D.S. Clinical risk factors for severe Clostridium difficile-associated disease. Emerg. Infect. Dis. 2009, 15, 415-422. [CrossRef]

54. Koo, H.L.; Garey, K.W.; Dupont, H.L. Future novel therapeutic agents for Clostridium difficile infections. Expert Opin. Investig. Drugs 2010, 19, 825-836. [CrossRef]

55. Roshan, N.; Riley, T.V.; Hammer, K.A. Antimicrobial activity of natural products against Clostridium difficile in vitro J. Appl. Microbiol. 2017, 123, 92-103. [CrossRef]

56. Roila, R.; Ranucci, D.; Valiani, A.; Galarini, R.; Servili, M.; Branciari, R. Antimicrobial and anti-biofilm activity of olive oil by-products against Campylobacter spp. isolated from chicken meat. Acta Sci. Pol. Technol. Aliment. 2019, 18, 43-52.

57. Roila, R.; Branciari, R.; Ranucci, D.; Ortenzi, R.; Urbani, S.; Servili, M.; Valiani, A. Antimicrobial activity of olive mill wastewater extract against Pseudomonas fluorescens isolated from mozzarella cheese. Ital. J. Food Saf. 2016, 5, 5760. [CrossRef]

58. Roila, R.; Valiani, A.; Ranucci, D.; Ortenzi, R.; Servili, M.; Veneziani, G.; Branciari, R. Antimicrobial efficacy of a polyphenolic extract from olive oil by-product against “Fior di latte" cheese spoilage bacteria. Int. J. Food Microbiol. 2019, 295, 49-53. [CrossRef] 